\title{
THE EFFECT OF SILKWORM PUPAE (Bombyx mori) MEAL TO SUBSTITUTE FISH MEAL ON PRODUCTION AND PHYSICAL QUALITY OF QUAIL EGGS (Cortunix cortunix japonica)
}

\author{
R. Rahmasari ${ }^{1}$, Sumiati ${ }^{2}$ and D. A. Astuti ${ }^{2}$ \\ ${ }^{1}$ Study Program of Nutrition and Feed Science, Faculty of Animal Science, \\ Bogor Agricultural University, Jl. Agatis, Darmaga Campus, Bogor 16680 - Indonesia \\ ${ }^{2}$ Department of Nutrition and Feed Technology, Faculty of Animal Science, \\ Bogor Agricultural University, Jl. Agatis, Darmaga Campus, Bogor 16680 - Indonesia \\ Corresponding E-mail:y_sumiati@yahoo.com
}

Received June 07, 2014; Accepted August 14, 2014

\begin{abstract}
ABSTRAK
Tujuan penelitian ini adalah untuk mengetahui efek substitusi protein tepung ikan dengan tepung pupa ulat sutera (Bombyx mori) terhadap performa produksi dan kualitas telur pada puyuh. Penelitian ini menggunakan rancangan acak lengkap (RAL) dengan empat perlakuan dan empat ulangan dengan sepuluh ternak tiap ulangan. Perlakuan yang diberikan adalah R0: pakan mengandung $8 \%$ tepung ikan, tanpa tepung pupa ulat sutera (kontrol), R1: pakan mengandung tepung pupa ulat sutera menggantikan $25 \%$ protein tepung ikan, R2: pakan mengandung tepung pupa ulat sutera menggantikan $50 \%$ protein tepung ikan, dan R3: pakan mengandung tepung pupa ulat sutera menggantikan $75 \%$ protein tepung ikan. Hasil penelitian menunjukkan bahwa substitusi tepung pupa ulat sutera $25-75 \%$ nyata menurunkan $(\mathrm{P}<0.05)$ nilai konversi ransum, nyata meningkatkan $(\mathrm{P}<0.05)$ produksi telur tanpa mempengaruhi kualitas fisik telur yang dihasilkan. Kesimpulan yang dapat diambil adalah tepung pupa ulat sutera dapat digunakan $25-75 \%$ menggantikan protein tepung ikan.
\end{abstract}

Kata kunci: puyuh, telur, tepung ikan, tepung pupa ulat sutera

\begin{abstract}
The aims of this study was to determine the effect of substitution of fish meal protein with silkworm pupae (Bombyx mori) on quail performances and egg quality. The experiment was a completly randomized design (CDR) with four treatments and four replications and ten birds of each replication. The treatment diets were R0: diet contain $8 \%$ fish meal, without silkworm pupae (control), R1: diet contain silkworm pupae subtituted of $25 \%$ fish meal protein, R2: diet contain silkworm pupae subtituted of 50\% fish meal, protein and R3: diet contain silkworm pupae subtituted of $75 \%$ fish meal protein. The results showed that substitution of $25 \%$ up to $75 \%$ significantly $(\mathrm{P}<0.05)$ reduced feed conversion ratio, significantly $(\mathrm{P}<0.05)$ increased egg production and did not affecting physical quality of quail eggs. In conclusion, silkworm pupae can be used $25 \%$ up to $75 \%$ replacing protein fish meal.
\end{abstract}

Keywords: egg, fish meal, quail, silk worm pupae

\section{INTRODUCTION}

Livestock is one of the important business in an effort to meet the needs of animal protein for the people. One important factor is the availability of feed. The availability of feed must be guaranteed in quality, quantity, and continuity. In addition, the price of raw materials is also a concern in the preparation of rations that will have an impact on the cost of production. Fish meal is the animal protein supplements most widely used by the feed industry. 
Feed industry in Indonesia need fish meal about 100,000-120,000 tons per year and most of it is fulfilled with imported one as much as 50,000-65,000 tons (Statistic Indonesia, 2012). This amount would require a very large foreign exchange. Price of imported fish meal was almost the same as the local fish meal, but imported fish meal has a better quality. This makes not a lot of local fish meal used in feed industry, so the price becomes expensive. The quality of local fish meal is very low with crude protein content below $55 \%$ (National Standardization Agency of Indonesia, 1996) and it becomes an important constraint. Therefore, it needs a solution to reduce the use of fish meal by substituting with high quality ingredient and affordable prices. One of the ingredient that can be used is industrial waste such as silkworm pupae.

Silkworm pupae is potential to be used as animal feed. The average cocoon production in Indonesia since 2005-2009 reached 166,262,03 kg which resulted $23,176.376 \mathrm{~kg}$ yarn $(13.16 \%)$. It shows that $143,085.654 \mathrm{~kg}(86.84 \%)$ become waste. (Balai Persuteraan Alam, 2011). Although the product is still relatively small, the potential in the future can still be developed, because Indonesia still imports the silk fabrics from other countries. Recorded in 2009 the national silk yarn needed 900 tons/year. South Sulawesi, for example, requires about 250 tons per year and will be met from local production of about 15.789 kg. In South Sulawesi centers silkworms just focused on Soppeng, Wajo, and Sidrap. Mulberry plants are grown in other districts such as Barru, Bone, Enrekang, Bulukumba, and some other districts with a total area of $2.524,8$ acres has not been developed as a silkworm cultivation. The development of silk industry in the future by increasing the production of yarn, waste silkworm pupae production will also increase, so that is potential to be animal feed.

Waste from silk industry is widely used today is the silkworm wrapper. Utilization of this waste in Indonesia is only for the manufacture of accessories. The pupae will quickly rot and cause the unpleasant smell that can be pollution to environment. In some countries such as Korea, Japan, and China silkworm pupae has been used as snacks, canned food, alternative food diabetics, candles, and beauty products such as soaps and hair tonic. As recorded, Chinese people started cultivating artificial Bombyx mori L. 5200 years ago, eating insects 3200 years ago, people in Jiangsu, Zhejiang and the three northeastern provinces areas like the edible chrysalis Bombyx mori L. (Yi et al., 2010). It is make researchers interest to study about silkworm pupae. Some research have been done indicated that silkworm pupae contain high nutrients. Pereira et al. (2003) reported that silkworm pupae meal contain $51.1 \%$ of crude protein and $34.4 \%$ of crude fat. Silkworm pupae also have a good EAA (essential amino acids) content, such as EAA from silkworm Antheraea pernyi (406.2 mg/g protein), Bombyx mori $(431 \mathrm{mg} / \mathrm{g}$ protein) and that is higher than that of egg (388.2 $\mathrm{mg} / \mathrm{g}$ protein) (Zhou and Han, 2006). Which such that quality, silkworm pupae potential as an alternative feed ingredients.

Silkworm pupae also contain $32.52 \%$ of saturated fatty acids and $67.48 \%$ of unsaturated fatty acid with linoleic acid (omega 6) $8.57 \%$ and linolenic acid (omega 3) 24.4\% (Pereira et al. 2003). Both types of unsaturated fatty acids have been a lot of concern for people considering the benefits for the body. Handini et al. (2006) suggested that increasing consumption of omega3 can reduce the risk of death due to cardiovascular disease (atherosclerosis and coronary heart disease), cancer, tumors and may improve the body's immune system. Deficiency of fatty acid can cause interference with the nervous system and visual abilities. Deficiency of omega6 also have an impact on health such as slow growth and skin sores or flaky (Gopper et al. 2009).

Egg is one of the many farm products consumed by the public, egg has a complete nutrient content and good biological value. According to Vaghefi (2002), eggs contain protein, fat, water, some vitamins such as vitamin $\mathrm{A}, \mathrm{B}, \mathrm{D}$ and $\mathrm{E}$ as well as minerals such as $\mathrm{P}, \mathrm{Mg}$, $\mathrm{Fe}, \mathrm{Cu}$, and $\mathrm{Zn}$ which are beneficial for the body. One of the many eggs that are consumed was quail eggs. The nutrient content of eggs can be enhanced by the provision of a quality diet. The one solution to increase the quality diet is by giving silkworm pupae meal which high in protein and unsaturated fatty acids. Giving silkworm pupae meal can be done by substitution of fish meal. The aim of this study was to determine the effect of substitution of protein fish meal with silkworm pupae (Bombyx mori) on quail performances and egg quality.

\section{MATERIALS AND METHODS}

Silkworm pupae waste were collected from "Pabrik Benang Sutera" PSA Regaloh, KBM 
Agroforestri, Perum Perhutani Unit 1, Telogowungu, Central Java. The upper silk layer was discarded by cutting the upper layer, then the pupae were sun dried and ground to be powder. The feeding trial in this experiment used 160 quails pullet.

The experiment was a completly randomized design (CDR) with four treatments and four replications with ten quails of each replication those were place in $60 \times 60 \times 40 \mathrm{~cm}$ pen The diet treatments were R0: diet contained $8 \%$ of fish meal, without silkworm pupae (control), R1: diet contained silkworm pupaeto subtitute $25 \%$ of fish meal protein R2: diet contained silkworm pupae to subtitute of $50 \%$ fish meal protein, and R3: diet contained silkworm pupae to subtituteof $75 \%$ fish meal protein. The diets were formulated iso caloric and iso protein according to recommendation of Leeson and Summers (2005) (Table 1).

Quails were reared for ten weeks, one week for environmental adaptation, one week for adaptation treatment and eight weeks for diet treatment. Diet and drinking water were offered ad libitum. Feed intake was measured every week, egg production and egg weight recorded every

Table 1. Composition and Nutrient Content of Treatment Diet

\begin{tabular}{|c|c|c|c|c|}
\hline \multirow{2}{*}{ Ingredients } & \multicolumn{4}{|c|}{ Treatment } \\
\hline & $\mathrm{R} 0$ & $\mathrm{R} 1$ & $\mathrm{R} 2$ & R3 \\
\hline & \multicolumn{4}{|c|}{ (\%) } \\
\hline Maize & 50.13 & 50.09 & 50.35 & 51.3 \\
\hline Rice bran & 6.87 & 6.3 & 6.09 & 6 \\
\hline Soybean meal & 23 & 23.43 & 22.9 & 22.3 \\
\hline Fish meal & 8 & 6 & 4 & 2 \\
\hline Silkworm pupae & 0 & 2.08 & 4.16 & 6.25 \\
\hline Oil & 4.5 & 4.45 & 4.5 & 4.2 \\
\hline $\mathrm{CaCO}_{3}$ & 6.6 & 6.75 & 6.9 & 6.85 \\
\hline DCP & 0 & 0 & 0.3 & 0.3 \\
\hline DL-Methionine & 0.2 & 0.2 & 0.1 & 0.1 \\
\hline Salt & 0.2 & 0.2 & 0.2 & 0.2 \\
\hline Premix & 0.5 & 0.5 & 0.5 & 0.5 \\
\hline Total & 100 & 100 & 100 & 100 \\
\hline \multicolumn{5}{|l|}{ Nutrient content } \\
\hline Energy bruto $(\mathrm{kkal} / \mathrm{kg})^{1}$ & 3262 & 3216 & 3309 & 3316 \\
\hline Crude protein $(\%)^{2}$ & 17.27 & 17.08 & 16.77 & 17.34 \\
\hline $\mathrm{Ca}(\%)$ & 3.08 & 3.03 & 3.04 & 2.91 \\
\hline $\mathrm{P}$ available (\%) & 0.52 & 0.45 & 0.45 & 0.39 \\
\hline Crude fiber $(\%)^{2}$ & 2.11 & 2.62 & 2.60 & 2.51 \\
\hline Crude fat $(\%)^{2}$ & 3.84 & 4.64 & 5.67 & 5.09 \\
\hline Methionine (\%) & 0.63 & 0.66 & 0.58 & 0.60 \\
\hline Methionine + Cysine $(\%)$ & 0.76 & 0.79 & 0.81 & 0.83 \\
\hline Lysine (\%) & 1.30 & 1.34 & 1.36 & 1.38 \\
\hline
\end{tabular}

${ }^{1}$ Result from analysis at Indonesian Research Institute for Animal Production,

2 Result from analysis at Laboratory of Nutrition and Feed Technology Faculty of Animal Science, Bogor Agricultural University, 2014 
day during the treatment. Physical quality of egg was observed at the first, second, third, fourth, and eighth week of the treatment. Three eggs were taken from each replication for physical quality analysis. The variable observed in this study were quail performance: feed consumption, quail day egg production, egg mass production, feed conversion, and egg physical quality.

\section{Statistical Analysis}

Data obtained were analyzed by analysis of variance (ANOVA), if there was a significant different, the data were further analysed using Duncan's multiple range test (Mattjik and Sumertajaya, 2002).

\section{RESULTS AND DISCUSSION}

\section{Feed Consumption}

The statistical analysis showed that the treatments did not affect the feed intake. Feed consumption on this experiment was 15.03-16.60 $\mathrm{g} / \mathrm{bird} /$ day higher than consumption on Suripta et al. (2007) is $15.4 \mathrm{~g} / \mathrm{bird} /$ day. According to Dewi and Setiohadi (2010) feed intake was influenced by several factors such as age and size of bird, palatability and feed quality. It indicated that fed silkworm pupae meal did not affect the feed palatability. Silkworm pupae meal has similar texture, smell, and quality as fish meal. Feed consumption of laying hens fed silkworm pupae meal of $100 \%$ replaced fish meal protein $(8 \%$ in the diet) differ markedly lower than that of fed 25$75 \%$ replace fish meal protein (Mangisah et al., 2004).

\section{Egg Production}

The results showed that subtitution of $25 \%$ or $75 \%$ fish meal protein with silkworm pupae (R1 or R3) significantly increased egg production
$(\mathrm{P}<0.05)$ compared to $\mathrm{R} 0$. Egg production at $\mathrm{R} 0$ significant lower than R1 and R3, but not significantly different with R2. Egg production in R0 lower than another treatments in line with the low feed intake, that was influanced with nutrient consumption. Energy consumption was not different between treatments $(\mathrm{P}>0.05)$. However, any different on protein consumption, that could be astimate affected egg production among the treatments. Table 2 shows that $\mathrm{R} 0$ has a lower real protein intake $(\mathrm{P}<0.05)$ compared to $\mathrm{R} 1, \mathrm{R} 2$, and $\mathrm{R} 3$. Low consumption of proteins in R0 may be caused by a low quality protein in $\mathrm{R} 0$ diet compared ration protein quality in R1, R2, and R3 diet. Substitution of fish meal with flour pupae could be expected to improve the quality of diet. Silkworm pupae have lower protein $(51.1 \%)$ compared to fish meal (60\% protein). Despite silkworm pupae have lower crude protein content, metabolizable energy content, unsaturated fatty acids, and amino acid composition of silkworm pupae higher than fish meal (Leeson and Summers, 2005; Pereira et al. 2003). Wijayasinghe and Rajaguru (1977), diet contain $7.5 \%$ silkworm pupae have protein and amino acid value same with diet containing $10 \%$ of fish meal and $2 \%$ of skim milk. Chicken egg production by administration of silkworm pupa meal as much as $6 \%$ was significantly higher $(\mathrm{P}<0.01)$ in comparison with diet without silkworm pupae meal. The egg production with diet silkworm pupae significant difference suggests that the quality of silkworm pupae protein was better than protein concentrate for laying hen (Khatun et al., 2005). Mangisah et al. (2004) showed that substitution of silkworm pupae meal replace $25-75 \%$ of fish meal protein in the diet was not significantly different from controls. Total egg production for research on R0 is also markedly lower than the R1, R2, and R3,

Table 2. The Average of Feed Consumption, Energy Consumption, Protein Consumption, and Fat Consumption during 8 Weeks Treatment

\begin{tabular}{ccccc}
\hline Treatment & $\begin{array}{c}\text { Feed Consumption } \\
\text { (g/bird/day) }\end{array}$ & $\begin{array}{c}\text { Energy Consumption } \\
\text { (kkal/bird/day) }\end{array}$ & $\begin{array}{c}\text { Protein Consumption } \\
\text { (g/bird/day) }\end{array}$ & $\begin{array}{c}\text { Fat Consumption } \\
\text { (g/bird/day) }\end{array}$ \\
\hline R0 & $15.31 \pm 0.40$ & $49.93 \pm 1.30$ & $2.59 \pm 0.05^{\mathrm{a}}$ & $0.59 \pm 0.02^{\mathrm{a}}$ \\
R1 & $16.60 \pm 0.44$ & $53.38 \pm 1.43$ & $2.84 \pm 0.08^{\mathrm{b}}$ & $0.77 \pm 0.02^{\mathrm{b}}$ \\
R2 & $16.41 \pm 0.86$ & $54.29 \pm 2.86$ & $2.74 \pm 0.13^{\mathrm{ab}}$ & $0.93 \pm 0.05^{\mathrm{d}}$ \\
R3 & $16.44 \pm 1.05$ & $54.50 \pm 3.47$ & $2.85 \pm 0.18^{\mathrm{b}}$ & $0.84 \pm 0.05^{\mathrm{c}}$ \\
\hline
\end{tabular}

Different superscript in the same column indicate significantly difference $(\mathrm{P}<0.05)$ 
the highest production in $\mathrm{R} 1$. This is consistent with the value of the daily egg production $\mathrm{R} 1$ higher than the other treatments. Egg production is influenced by a combination of saturated fatty acids and unsaturated fatty acids on diet. According to Wathes et al. (2007), unsaturated fatty acids such as eicosapentaenoat (EPA) and arachidonat fatty acid (AA) were importent precursor for prostaglandin, prostacycline, thromboxane, and leukotriene. Prostaglandins such as FSH (folicel stimulating hormone) and LH (leutinizing hormone) have been implicated in many reproductive functions (Abayasekara and Wathes, 1999).

\section{Feed Conversion}

Feed conversion expressed as feed required per $\mathrm{kg}$ of egg mass. The amount of feed conversion in layer is determined by the amount of feed intake, egg number and weight of eggs produced. The average of feed conversion in this study is 3.35-4.21 (Table 3). Feed conversion in treatments of R1, R2, and R3 are markedly lower than control $(\mathrm{R} 0)(\mathrm{P}<0.05)$. This was because the daily and total egg production on R1, R2, and R3 were higher than R0. Substitution of silkworm pupae meal did not affect the feed efficiency. Substitution of silkworm pupae meal replace fish meal up to $75 \%$ in laying hens diet had a feed conversion rate equal with control (Mangisah et al., 2004). This is estimate due to the subtitution of silkworm pupae meal make nutrient contain on diet better. Amino acids and unsaturated fatty acids from silkworm pupae supplement nutrient diet content. The content of amino acids and essential fatty acids on diet can promote high productive performance in broiler chicken (Jintasataporn, 2012)

\section{Egg Physical Quality}

Egg physical quality were observed as egg weight, yolk color score, Haugh unit, egg white weight, yolk weight, shell weight, and shell thickness. The observation and analysis of variance of each variable are presented in Table 4. Substitution of silkworm pupae meal was not significantly different $(\mathrm{P}>0.05)$ in scores yolk color, Haugh unit, yolk weight, shell weight, and shell thickness. However, the substitution of silkworm pupae meal significant effect on increasing egg weight and egg white weight $(\mathrm{P}<0.05)$.

Yolk color scores were not different indicating that substitution of silkworm pupae meal does not affect the color of egg yolks. Yolk color is influenced by the presence of pigment xanthophylls, lutein, zeaxanthin, as well as synthetic pigments such as canthaxanthin and apocarotenoic esters in the feed. Feed ingredients rich in xanthophylls are corn and corn gluten meal (Leeson and Summers, 2005). Yolk color scores were not different because the amount of corn on diet have same ration. Haugh unit is a value that determines the quality of egg freshness. The average of Haugh unit in this study is 92.01 92.72 (Table 4) and that value was higher than the results of the study by Dudusola (2010), that was 84.19. The analysis showed that the Haugh unit values were not significantly different between treatments. It is demonstrated that substitution of silkworm pupae meal does not affect the quality of the eggs. In this research results showed that the egg include in grade AA. According to Yuwanta (2004), egg Haugh unit values above 72 are categorized egg quality AA, Haugh units 6072 A quality eggs, Haugh units 31-60 B quality eggs, and Haugh unit values less than 31 egg quality $\mathrm{C}$. Haugh unit value which did not differ due to each egg is stored in the same place and time. Factors that affect the value of Haugh units of which time and place of storage of egs, age and type of livestock, nutrient feed, disease, and supplementation (vitamins $\mathrm{C}$ or E) and diseases (Roberts, 2010; Gerber, 2006).

Yolk weight associated with egg weight, egg white weight, and shell weight. Egg yolk and shell weight did not differ between treatments, but the egg white weight different between treatments. The differences of egg white weight is in line with the different of egg weight between treatments. This suggests that the largest composition of egg is white egg. Weight and eggshell thickness were not different between treatments, it may be caused by calcium content in the diet to be similar. Calsium is the major component in egg shell (Shen and Chen, 2003). Egg shell quality is influenced by the availability of $\mathrm{Ca}$ and $\mathrm{P}$. Both of the minerals aimed at optimizing shell calcification. The higher the calcium concentration in diet, the better shell quality and shell thickness (Leeson and Summers, 2001).

The average of egg weight of this study ranged from 8.40-8.92 $\mathrm{g} / \mathrm{egg}$. The result showed that egg weight in R2 was significantly higher than R0, R1, and R3 $(\mathrm{P}<0.05)$. Egg weight was lower than the results of the study by Song et al. (2000) that is $10.34 \mathrm{~g}$. Egg weight associated with the type of quail. According to Hrncar et al. 
Table 3. The Average Egg Productin (Hen Day), Total of Egg Production, and Feed Conversion during 8 Weeks of Treatment

\begin{tabular}{cccc}
\hline Treatment & Egg Production/han day $(\%)$ & Total Egg Production & Feed Conversion \\
\hline R0 & $43.74 \pm 5.34^{\mathrm{a}}$ & $223.25 \pm 21.75^{\mathrm{a}}$ & $4.84 \pm 0.70^{\mathrm{b}}$ \\
R1 & $58.44 \pm 2.48^{\mathrm{c}}$ & $327.25 \pm 13.89^{\mathrm{c}}$ & $3.45 \pm 0.14^{\mathrm{a}}$ \\
R2 & $49.59 \pm 3.10^{\mathrm{ab}}$ & $262.50 \pm 14.48^{\mathrm{b}}$ & $3.87 \pm 0.27^{\mathrm{a}}$ \\
R3 & $53.21 \pm 4.21^{\mathrm{bc}}$ & $282.50 \pm 17.62^{\mathrm{b}}$ & $3.87 \pm 0.06^{\mathrm{a}}$ \\
\hline
\end{tabular}

Different superscript in the same column indicate significantly difference $(\mathrm{P}<0.05)$

Table 4. The Average of Egg Weight, Yolk Score, Haugh Unit

\begin{tabular}{lrrrr}
\hline \multicolumn{1}{c}{ Parameter } & \multicolumn{1}{c}{$\mathrm{R} 0$} & \multicolumn{1}{c}{$\mathrm{R} 1$} & \multicolumn{1}{c}{$\mathrm{R} 2$} & \multicolumn{1}{c}{$\mathrm{R} 3$} \\
\hline Egg weight (g) & $8.40 \pm 0.14^{\mathrm{a}}$ & $8.48 \pm 0.11^{\mathrm{a}}$ & $8.92 \pm 0.10^{\mathrm{b}}$ & $8.44 \pm 0.28^{\mathrm{a}}$ \\
White egg weight (g) & $4.61 \pm 0.22^{\mathrm{ab}}$ & $4.54 \pm 0.19^{\mathrm{a}}$ & $4.89 \pm 0.21^{\mathrm{b}}$ & $4.37 \pm 0.22^{\mathrm{a}}$ \\
White egg percentage (\%) & $54.09 \pm 0.79$ & $54.38 \pm 0.47$ & $54.62 \pm 0.82$ & $53.20 \pm 3.97$ \\
Yolk weight (g) & $2.76 \pm 0.18$ & $2.71 \pm 0.16$ & $2.85 \pm 0.19$ & $2.64 \pm 0.13$ \\
Yolk percentage (\%) & $33.37 \pm 0.35$ & $32.27 \pm 0.38$ & $32.74 \pm 0.86$ & $33.49 \pm 3.36$ \\
Egghell weight (g) & $1.07 \pm 0.07$ & $1.12 \pm 0.06$ & $1.12 \pm 0.01$ & $1.07 \pm 0.07$ \\
Eggshell percentage (\%) & $12.53 \pm 0.93$ & $13.35 \pm 0.39$ & $12.64 \pm 0.40$ & $13.31 \pm 0.78$ \\
Eggshell thickness (mm) & $0.15 \pm 0.02$ & $0.15 \pm 0.00$ & $0.15 \pm 0.01$ & $0.15 \pm 0.01$ \\
Haugh unit & $92.72 \pm 0.61$ & $92.04 \pm 0.61$ & $92.23 \pm 0.76$ & $92.01 \pm 1.51$ \\
Yolk score & $5.93 \pm 0.19$ & $6.05 \pm 0.23$ & $6.50 \pm 0.19$ & $6.33 \pm 0.61$ \\
\hline
\end{tabular}

Different superscript in the same row indicate significantly difference $(\mathrm{P}<0.05)$

(2014), eggs from quail meat type (13.06 g) was bigger than eggs laying type (11.48 g). The others factors are the weight and age of livestock, energy content, fat, linoleic acid, protein, and amino acids such as methionin (Leeson and Summers, 2005). Silkworm pupae meal contains linoleic acid $8.57 \%$ and linolenic acid $24.4 \%$, with the total unsaturated fatty acids $67.48 \%$ (Pereira et al., 2003). The average of egg whites during this study can be seen in Table 4. The results showed that the egg white weight was significantly, R2 higher than R1 and R3, but not different from R0. This is consistent with the egg weight was produced. The heavily of egg white weight influenced by the egg weight. Heavy egg white in the study ranged 4.37-4.89 $\mathrm{g}$ with the percentage of egg white weight is $53.20-54.62 \%$. According to Yuwanta (2010), normal range of quails egg white weight is 4.1-6 g per egg with egg white weight percentage of $52-60 \%$ from hole egg.

\section{CONCLUSION}

Subtitute silkworm pupae meal $2.08 \%$ to $6.25 \%$ to replace of $25-75 \%$ fish meal protein given a good results in terms of egg production, feed conversion, without negative effect on egg quality.

\section{REFERENCES}

Abayasekara, D.R.E. and D.C. Wathes. 1999. Effects of altering dietary fatty acid composition on prostaglandin synthesis and fertility. Prostaglandin, Leukotrienes and Essential Fatty Acid. 61(5):275-287 
Balai Persuteraan Alam. 2010. Statistik Pengembangan Persuteraan Alam Tahun 2010. Departemen Kehutanan. Direktorat Jenderal Rehabilitasi Lahan dan Perhutanan Sosial. Bili-Bili, February 2010.

Dewi, S.H.C. dan J. Setiohadi. 2010. Pemanfaatan tepung pupa ulat sutera (Bombyx mori) untuk pakan puyuh (Cortunix cortunix japonica) jantan. Jurnal AgriSains 1(8):1-6

Dudusola, I.O. 2010. Comparative evaluation of internal and external qualities of eggs from quail and guinea fowl. International Res. J. Plant Sci. 1(5):112-115

Gerber, N. 2006. Factors affecting egg quality in the commercial laying hen: a review. Poultry Industry Association of New Zealand, Auckland. www.eggfarmers.org.nz.

Gropper, S.S., J.L. Smith and J.L. Groff. 2009. Advanced Nutrition and Human Metabolism. 5th Ed. Wadsworth Cengage Learning, Belmont, USA.

Hardini, D., T. Yuwanta, Zuprizal and Supadmo. 2006. The change in cholesterol content of long chain fatty acid egg during processing and its influence to the Rattus norvegicus $\mathrm{L}$. blood cholesterol content. J. Ilmu Ternak Vet.11(4):260-265.

Hrncar, C., E. Hanusova, A. Hanus and J. Bujko. 2014. Effect of genotype on egg quality characteristics of japanese quail (Cortunix japonica). Slovak J. Anim. Sci. 47(1):6-11.

Jintasataporn, O. 2012. Production performance of broiler chickens fed with silkworm pupa (Bombyx mori). J. Agric. Sci. Tech. 2(2012): 505-510

Khatun, R., S.A. Azmal, M.S.K. Sarker, M.A. Rashid, M.A. Hussain and M.Y. Miah. 2005. Effect of silkworm pupae on the growth and egg production performance of rhode island red (RIR) pure line. J. Poult. Sci. 4(9):718720.

Leeson, S and J.O. Atteh. 1995. Utilization of fats and fatty acids by Turkey poults. Poult. Sci. 74:2003-2010.

Leeson, S and J.D. Summers. 2001. Nutrition of The Chicken. Ed: $4^{\text {th }}$. Canada, University Books.

Leeson, S and J.D. Summers. 2005. Commercial Poultry Nutrition. Ed: $3^{\text {rd }}$ England, Nottingham University Press. p.198.205.

Mangisah, I., I. Estiningdriati and S. Sumarsih. 2004. Konsumsi pakan dan produksi telur akibat penggantian tepung ikan dengan tepung pupa dalam ransum. J. Indonesian Trop. Anim. Agric 29(1):39-43

Mattjik, A.A dan M. Sumertajaya. 2002. Perancangan Percobaan dan Aplikasi SAS dan Minitab. Jilid I. Edisi ke 2. Bogor (ID): IPB Press.

National Standardization Agency of Indonesia (SNI). 1996. Tepung Ikan Bahan Baku Pakan. SNI 01-2715-1996/Rev.92

Pereira, N.R., O. Ferrarese-Filho and M. Matsushita. 2003. Proximate composition and fatty acid profile of Bombyx mori L. chrysalis toast. J. Food Composition and Analysis 16:451-457

Roberts, J.R. 2010. Factors affecting egg shell and internal egg quality. $18^{\text {th }}$ Annual ASAIM SE Asian Feed Technology and Nutrition Workshop. 24-27 May 2010, Cambodia.

Shen, T.F. and W.L. Chen. 2003. The role of magnesium and calcium in eggshell formation in Tsaiya ducks and Leghorn hens. Asian-Australasian J. Anim. Sci. 16(2):290296

Song, K.T, S.H. Choi, and H.R. Oh. 2000. A comparison of egg quality of pheasant, chukar, quail and guinea fowl. Asian-Aust. J. Anim.Sci. 13(7): 986-990.

Statistic Indonesia (BPS). 2012. Statistik impor hasil perikanan menurut pelabuhan, provinsi dan negara asal impor. Pusat Data, Statistik, dan Informasi.

Suripta, H. and P. Astuti. 2006. Pengaruh penggunaan minyak lemuru dan minyak sawit dalam ransum terhadap rasio asam lemak omega-3 dan omega-6 dalam telur burung puyuh (Cortunix cortunix japonica). J.Indonesian Trop. Anim. Agric. 32(1):22-27

Vaghefi, S.B. 2002. Eggs and Health: Myths and Misconcentions. Dalam Eggs and Health Promotion. Edited by Ronald Ross Watson. Iowa State Press a Blacwell Publishing Company, Iowa. United State.

Wathes, D.C., D.R.E. Abayasekara and R.J. Aitken. 2007. Polyunsaturated fatty acids in male and female reproduction. Biol. Reprod. 77: 190-201

Wijayasinghe, M.S. and A.S.B. Rajaguru. 1977. Use of silkworm (Bombyx mori L.) pupae as a protein supplement in poultry rations. $\mathrm{J}$. Natn. Sci. Coun. Sri Lanka 5 (2): 95-104

Yi, C., Q. He, L. Wang and R. Kuang. 2010. The utilization of insect-resources in China rural area. J. Agr. Sc. 2(3):146-154

Yuwanta, T. 2004. Dasar Ternak Unggas. 
Kanisius, Yogyakarta, Yuwanta, T. 2010. Telur dan Kualitas Telur. Gadjah Mada University Press.

Zhou, J. D. Han. 2006. Proximate, amino and mineral composition of pupae of the silkworm Antheraea pernyi in China. J. Food Composition Analysis. 19:850-853. 